Check for updates

Cite this: RSC Adv., 2018, 8, 9941

\title{
$\beta$-Carotene: a natural osteogen to fabricate osteoinductive electrospun scaffolds $\uparrow$
}

\author{
Atiyeh Dabouian, ${ }^{a}$ Hadi Bakhshi, (D) *b Shiva Irani*a and Mohamad Pezeshki-Modaress ${ }^{c}$ \\ $\beta$-Carotene $(\beta C)$ as a natural osteogenic material was incorporated in PCL electrospun mats to fabricate \\ scaffolds for bone tissue engineering. These scaffolds successfully supported the attachment and \\ proliferation of mesenchymal stem cells (MSCs). Seeded scaffolds were calcinated during 21 days of cell \\ culture in a non-differential medium, which showed the osteodifferentiation of MSCs. Expression of \\ $R U N X 2$, SOX9, and osteonectin proved the osteoinductive effect of incorporated $\beta$-carotene on the \\ differentiation of MSCs to osteoblasts without using any external osteogenic differential agent. However, \\ the cells did not pass the early phase of osteogenesis and were still osteochondro-progenitor after 21 \\ days of incubation. Thus, the fabricated fibrous scaffolds are potential candidates for direct bone tissue \\ engineering.
}

Received 11th December 2017 Accepted 26th February 2018

DOI: 10.1039/c7ra13237a

rsc.li/rsc-advances proliferation, but also enhance osteogenic differentiation. For example, incorporation of hydroxyapatite (HA) into the formulations of scaffolds enhanced the osteoinductivity ${ }^{15,16}$ since bone is primarily composed of $\mathrm{HA}^{17}$. Furthermore, encapsulation of drugs such as dexamethasone, ${ }^{18,19}$ simvastatin, ${ }^{20}$ bone morphogenetic proteins ${ }^{21}$ and ascorbate2-phosphate ${ }^{19}$ within scaffolds and their sustained release improved the osteogenic differentiation of seeded MSCs.

$\beta$-Carotene $(\beta C)$ is the most abundant precursor of vitamin $A$ in the human diet and found in dark-green and orange fruits and vegetables. ${ }^{22,23}$ It is a natural bioactive component with electrical activity ${ }^{24,25}$ due to its conjugated double bonds (Fig. 1a). It can reduce bone loss in elder adults. ${ }^{26,27}$ The ability of $\beta$-carotene to induce osteogenic differentiation of stem cells has been reported. ${ }^{28-30}$ Although there are some recent articles about encapsulation of $\beta$-carotene within electrospun fibers, ${ }^{31-33}$ based on our literature survey, no research has been reported on the incorporation of $\beta$-carotene within electrospun scaffolds for tissue engineering applications.

This research aims to fabricate PCL fibrous mats containing $\beta$-carotene as bone tissue engineering scaffolds with the ability to self-differentiate MSCs to osteoblasts without using any osteogenic differential agent. Polycaprolactone (PCL) was chosen as a polymer with high mechanical strength, lack of toxicity and low $\operatorname{cost}^{34-36}$ for fabricating scaffolds via an electrospinning process. First, the morphology and biocompatibility of the mats for bone tissue engineering were evaluated and then, their performance in simulating the appropriate environment for the differentiation of MSCs to osteoblasts was studied.
${ }^{a}$ Department of Biology, School of Basic Sciences, Science and Research Branch, Islamic Azad University, 1477893855 Tehran, Iran

${ }^{b}$ Macromolecular Chemistry II, University of Bayreuth, Universitätsstraße 30, 95440 Bayreuth, Germany

${ }^{c}$ Tissue Engineering and Regenerative Medicine Institute, Tehran Central Branch, Islamic Azad University, Tehran, Iran.E-mail: hadi.bakhshi@uni-bayreuth.de; s.irani@srbiau.ac.ir $\dagger$ Electronic supplementary information (ESI) available: Experimental details and FTIR spectra. See DOI: 10.1039/c7ra13237a 
(a)

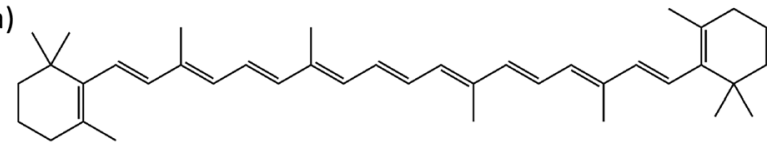

(b)

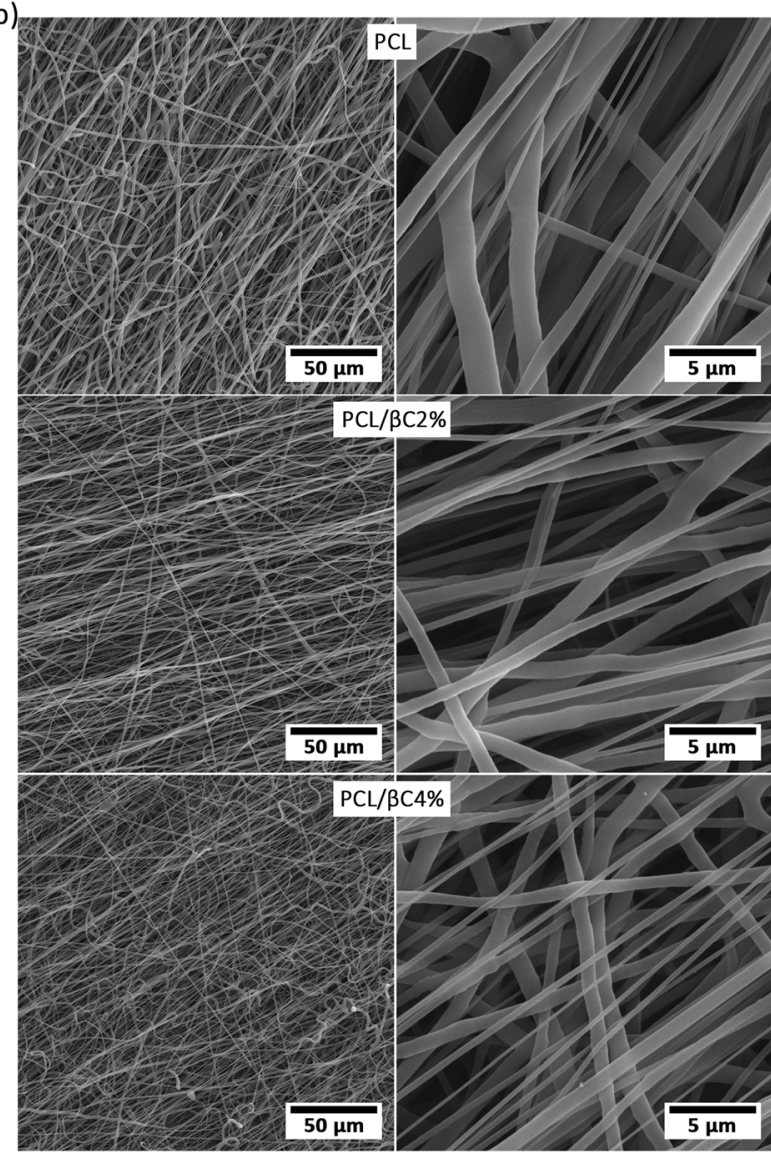

Fig. 1 (a) The molecular structure of $\beta$-carotene. (b) SEM images of the fabricated random fibrous mats.

\section{Experimental}

All experimental details, including materials, electrospinning process, instruments, and biological assays, are provided in the electronic supplementary information (ESI $\dagger$ ).

\section{Results and discussion}

\section{Fabrication of scaffolds}

Electrospinning is a proficient technique for the fabrication of a porous substrate with high surface area, similar to extracellular matrix (ECM); such a porous substrate is suitable for cell attachment and proliferation. ${ }^{18,37}$ PCL fibrous mats containing $\beta$-carotene $(0,2$ and $4 \mathrm{wt} \%$, called PCL, PCL/ $\beta \mathrm{C} 2 \%$ and $\mathrm{PCL} / \beta \mathrm{C} 4 \%$, respectively) were prepared via electrospinning process. SEM images (Fig. 1b) show that the fabricated mats consisted of randomly oriented fibers with an average diameter of $1.64 \pm 1.42,2.52 \pm 1.49$ and $1.87 \pm 0.98 \mu \mathrm{m}$. The pore size of mats was $6.45,5.15$ and $2.34 \mu \mathrm{m}$, respectively. The porosity of the mats was $49.3,52.8$ and $48.2 \%$. The mats contained large interconnected cavities, which are well-suited

to provide the appropriate biological conditions for guiding MSCs to osteoblasts.

The chemical structure of the electrospun mats was investigated by FTIR spectroscopy (Fig. S1-S3 in ESI $\dagger$ ). The FTIR spectra of all PCL mats were the same as that of virgin PCL, which indicated that no degradation or decomposition occurred during the electrospinning process. Due to the low content of $\beta$-carotene, no corresponding peak was observed in the FTIR spectra of the mats.

\section{Biocompatibility}

Scaffolds designed for tissue engineering should be biocompatible, so that cells can attach to these scaffolds and proliferate on them. Thus, the viability of MSCs $\left(10^{4}\right.$ cell per well) on the scaffolds $\left(0.5 \times 0.5 \mathrm{~cm}^{2}\right)$ after 24,48 , and 72 hours was evaluated. Optical microscope images (Fig. 2a) display that spindleshaped MSCs have proliferated and moved toward the scaffold. The MTT results (Fig. 2b) indicate no cytotoxicity effects for the scaffolds up to 72 hours; the cell viability of MSCs considerably improved $(p<0.001)$ on the third day. Incorporation of $\beta$-carotene within mats did not significantly change $(p>0.05)$ the viability of seeded MSCs. Moreover, the cell proliferation on the scaffolds was similar to that on the tissue culture plate used as the control.

A good attachment of MSCs on the scaffold after 48 hours was observed in SEM images (Fig. 2c), in which well-developed cell-cell and cell-matrix interactions are observed. DAPI assay was used after 48 hours to evaluate the adhesion of seeded MSCs with healthy nuclei. These results confirmed that the fabricated scaffolds are biocompatible and can support the attachment and proliferation of MSCs.

\section{Osteoblast differentiation}

Recent reports demonstrated the osteogenic effect of retinoic $\operatorname{acid}^{38}$ and $\beta$-carotene $e^{2,28-30}$ on cells. Nishide et al. ${ }^{28}$ studied the role of carotenoids in suppressing osteoclastogenesis. They activate cell signaling via binding to nuclear retinoic acid receptors (RARs). RARs attach to DNA as heterodimers with the retinoid X receptors (RXRs) and consequently modulate retinoic acid-responsive target genes. ${ }^{\mathbf{2 8 , 3 9 - 4 1}}$ Wang et al. $^{2}$ reported that $\beta$-carotene exerted an inhibitory effect on osteoclastogenesis and resorption pit formation through the nuclear factor-kappa B (NF- $\kappa \mathrm{B})$ pathway. To study the osteoinductive effect of $\beta$-carotene-containing mats on the differentiation of MSCs, scaffolds (PCL/ $\beta C 2 \%$ and PCL $/ \beta C 4 \%, 0.5 \times 0.5 \mathrm{~cm}^{2}$ ) were seeded with cells $\left(10^{4}\right.$ cell per well $)$ and kept in DMEM with $10 \%$ FBS as a non-differential medium for up to 21 days. For comparison, L-ascorbic acid $(10 \mathrm{mM})$ and dexamethasone $(1 \mathrm{mM})$ as external osteogenic differential agents ${ }^{15}$ were added to the cell culture medium used for the pure PCL scaffold. Optical microscopy images (Fig. 3a) shows the morphology change in osteodifferentiated cells on PCL/ $\beta \mathrm{C} 2 \%$ and PCL/ $\beta C 4 \%$ scaffolds after 21 days as compared to that on the tissue culture plate used as the control. A similar change was observed for cells on pure PCL scaffold cultured in the presence of external differential agents. 


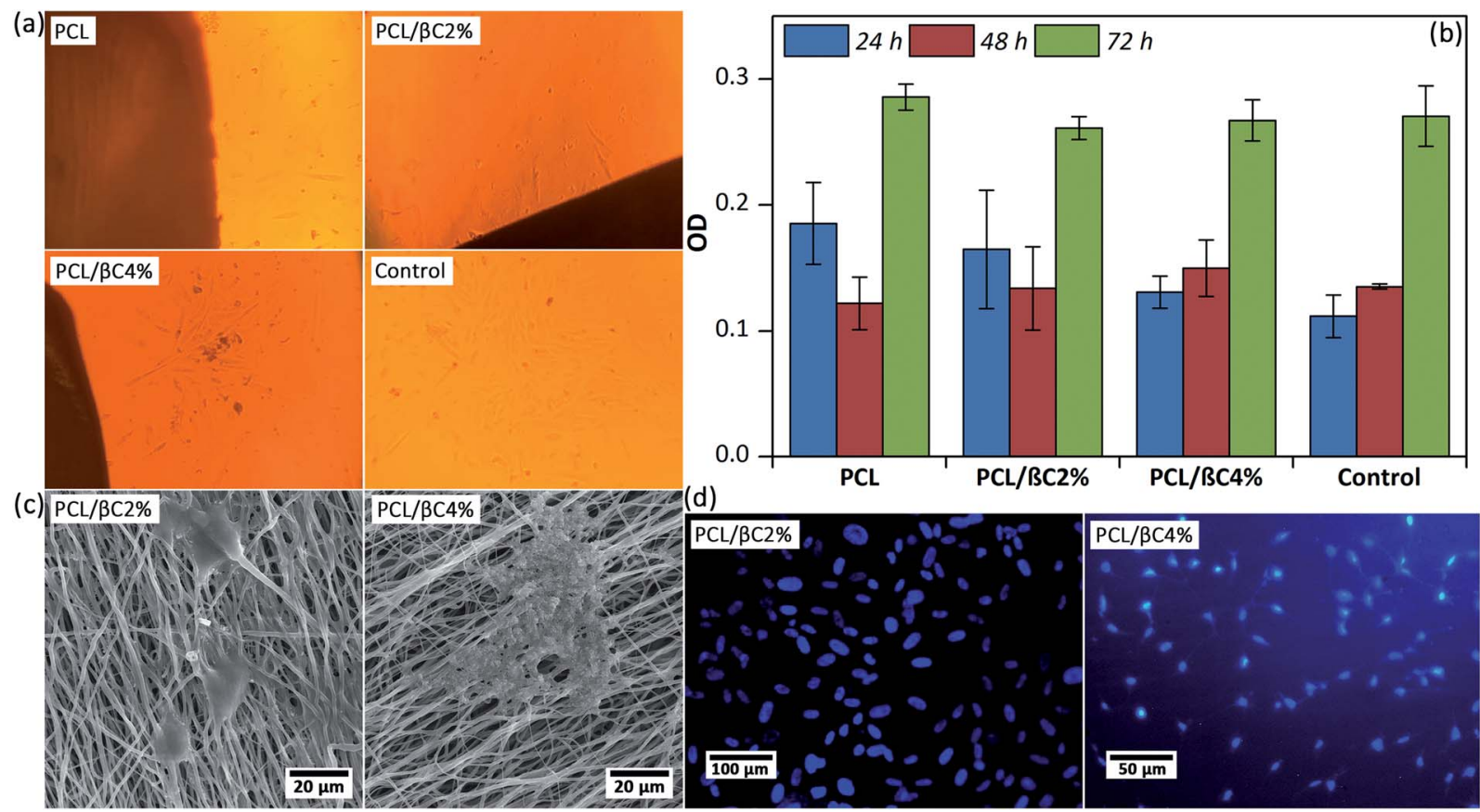

Fig. 2 (a) Optical microscopic images of MSCs $\left(10^{4}\right.$ cells per well) on the scaffolds $\left(0.5 \times 0.5 \mathrm{~cm}^{2}\right)$ after 24 hours. Tissue culture plate was used as the control. The magnification is 100. (b) The viability of MSCs on the scaffolds up to 76 hours obtained by MTT assay. (c) SEM images of the MSCs attached on the scaffolds after 48 hours. (d) DAPI staining images of the cell nucleus on the scaffolds after 48 hours.

The viability of cells on scaffolds during 21 days culture was evaluated by MTT assay (Fig. 3b). The number of cells on the scaffolds increased for up to 21 days, confirming their metabolic activity during this period. The viability of cells on PCL/ $\beta C 4 \%$ scaffold significantly decreased during the third week ( $p<$ 0.001 ) as compared to that on PCL $/ \beta C 2 \%$ scaffold and the control; this can be attributed to the differentiation of MSCs to osteoblasts. SEM images (Fig. 3c) show that the morphology of seeded MSCs on PCL $/ \beta C 4 \%$ completely changed to osteoblast after 14 days.

Alizarin red staining was performed to qualitatively evaluate the formation of mineralized matrix on the scaffolds. The results indicated the absorption of alizarin red dye on $\beta$-carotene containing scaffolds, particularly PCL $/ \beta C 4 \%$, due to the calcium deposed by osteodifferentiated cells (Fig. 4a). The intensity of absorbed dye increased over 21 days, indicating the progress of osteodifferentiation of cells during this period.

The quantity of calcium generated by the osteodifferentiated cells on scaffolds was measured via calcium content assay (Fig. 4b). The calcium content on scaffolds containing $\beta$-carotene increased over 21 days without using any external osteogenic differential agents, demonstrating the osteogenic osteoinductive effect of incorporated $\beta$-carotene for seeded MSCs. Moreover, low calcium content was detected for pure PCL scaffold, similar to the tissue culture plate, showing no differentiation of MSCs to osteoblasts.

The osteoinductivity of $\beta$-carotene within scaffolds for MSCs was assessed by evaluating the expression of RUNX2 and SOX9 genes in cells through reverse transcription polymerase chain reaction (RT-PCR). To this end, the total RNA of the cells was isolated and converted into cDNA by reverse transcriptase enzyme and polymerase chain reaction was then performed on the cDNA. The expression of $\beta 2 \mathrm{M}$ was recorded as a control gene. RUNX2 is the most important gene for following the osteogenic differentiation of MSCs. ${ }^{42}$ RT-PCR data (Fig. 5a) show the expression of RUNX2 (band at $81 \mathrm{bp)} \mathrm{for} \mathrm{both} \mathrm{PCL/}$ $\beta C 2 \%$ and $\mathrm{PCL} / \beta \mathrm{C} 4 \%$ scaffolds after 7 and 14 days, confirming the osteoinductive effect of $\beta$-carotene within scaffolds on the differentiation of seeded MSCs. Nishide et al. ${ }^{28}$ also reported that $\beta$-carotene increased RUNX2 expression in the MC3T3-E1 cell line. SOX9 is another gene expressed only in the early phase of osteogenesis; thus, when the cells pass this phase, SOX9 will no longer be expressed. ${ }^{42}$ RT-PCR data (Fig. 5a) display the expression of $S O X 9$ (band at $74 \mathrm{bp}$ ) for both PCL/ $\beta C 2 \%$ and $\mathrm{PCL} / \beta \mathrm{C} 4 \%$ scaffolds even after 14 days, which indicates that the cells did not pass the early phase of osteogenesis and were still osteochondro-progenitor.

Finally, the expression of osteonectin gene, a differentiation marker for bone cells ${ }^{43}$ was evaluated to approve the osteogenic differentiation of MSCs on PCL $/ \beta C 2 \%$ and PCL $/ \beta C 4 \%$ scaffolds. For this purpose, immunocytochemistry (ICC) assay was performed on cells seeded on scaffolds for 21 days. The fluorescence microscopic images (Fig. 5b) demonstrate the expression of osteonectin in a large number of cells, confirming the differentiation of seeded MSCs to osteoblasts as a result of the osteoinductive effect of incorporated $\beta$-carotene without any external differential agent.

It is worth mentioning that no degradation was observed in the PCL scaffolds during 21 days immersion in growth medium. Therefore, $\beta$-carotene should be released from the mats through a diffusion-out phenomenon before expressing its osteoinductive effect on the MSCs. 

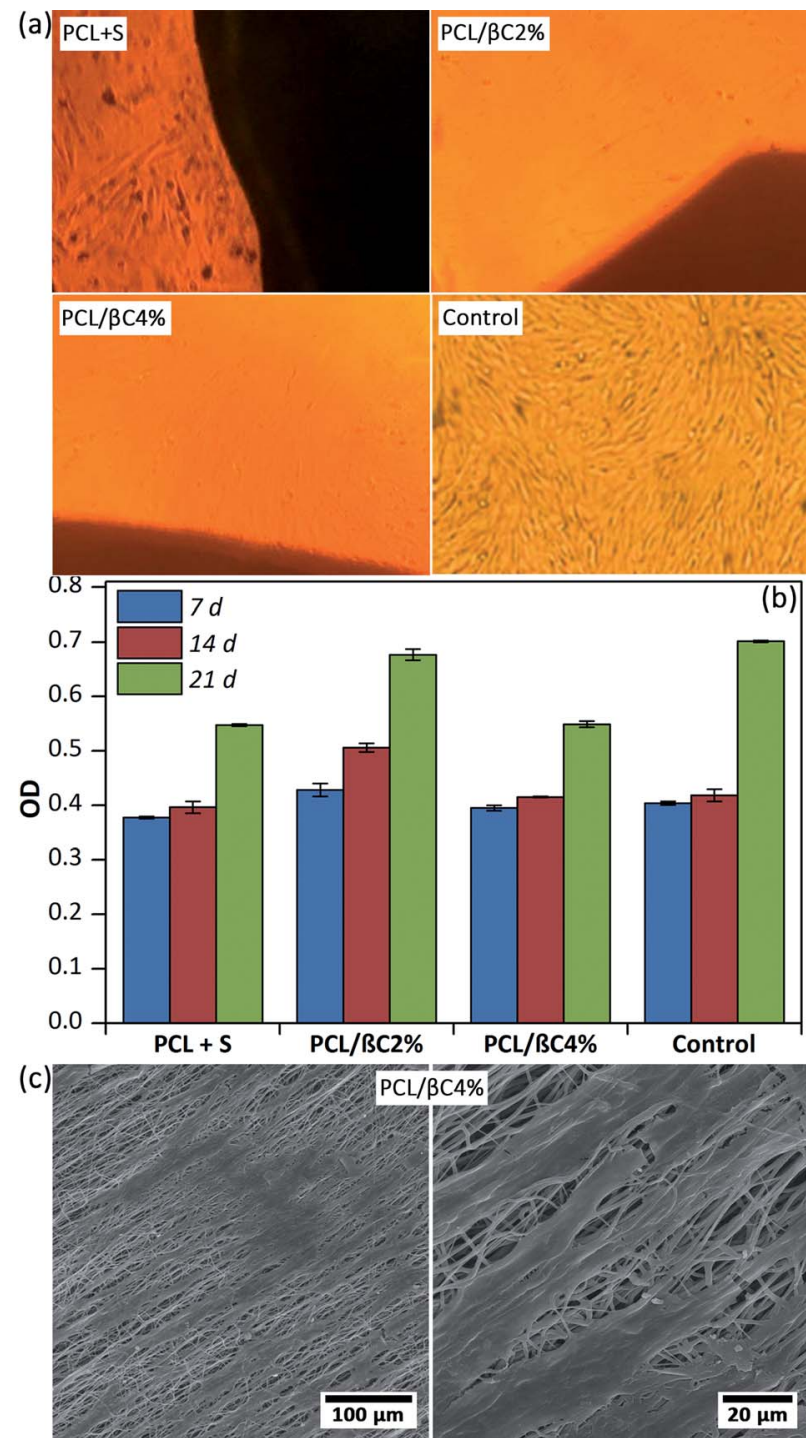

Fig. 3 (a) Optical microscopic images of differentiated cells $\left(10^{4}\right.$ cell per well) on the scaffolds $\left(0.5 \times 0.5 \mathrm{~cm}^{2}\right)$ after 21 days. Tissue culture plate was used as the control. S was L-ascorbic acid $(10 \mathrm{mM})$ and dexamethasone (1 mM). The magnification is 100. (b) The viability of the cells on the scaffolds up to 21 days obtained by MTT assay. (c) SEM images of the cells on PCL/ $\beta C 4 \%$ scaffold after 14 days.

\section{Conclusion}

The $\beta$-carotene-containing fibrous mats can be used as an excellent scaffold for bone tissue engineering to provide an appropriate environment for the osteodifferentiation of MSCs. The as-fabricated scaffolds were biocompatible and support the attachment and proliferation of seeded MSCs. Calcium content and ICC results confirmed the osteoinductive effect of $\beta$-carotene incorporated in the scaffolds on the differentiation of MSCs to osteoblasts without using any external osteogenic differential agent. However, RT-PCR results demonstrated that the cells did not pass the early phase of osteogenesis and were still osteochondro-progenitor after 21 days incubation.

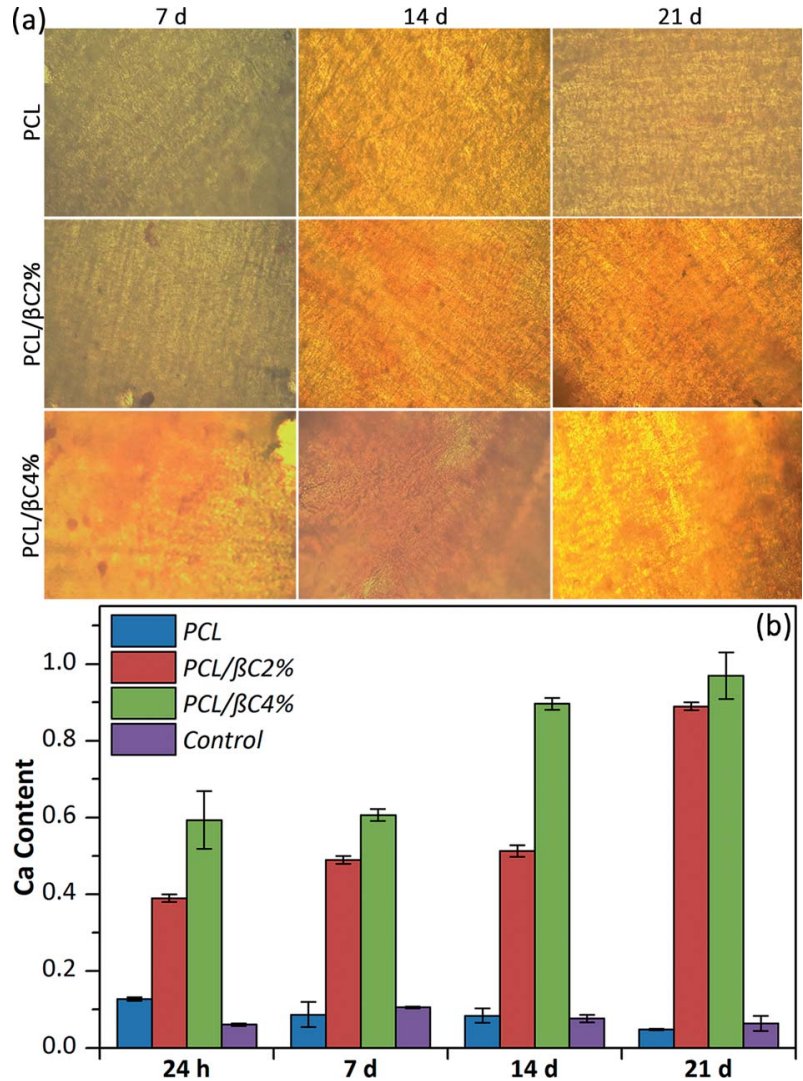

Fig. 4 (a) Alizarin red staining of the scaffolds seeded with MSCs cells $\left(10^{4}\right.$ cells per well). The magnification is 200 . (b) Calcium content of the scaffolds seeded with MSCs. Tissue culture plate was used as the control.

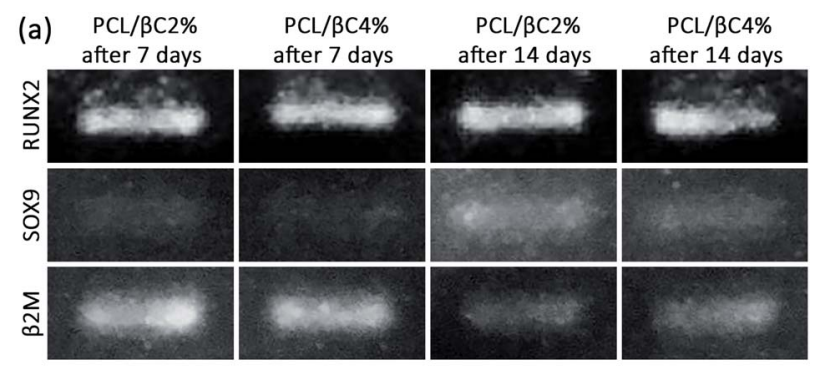

(b) Primary antibody
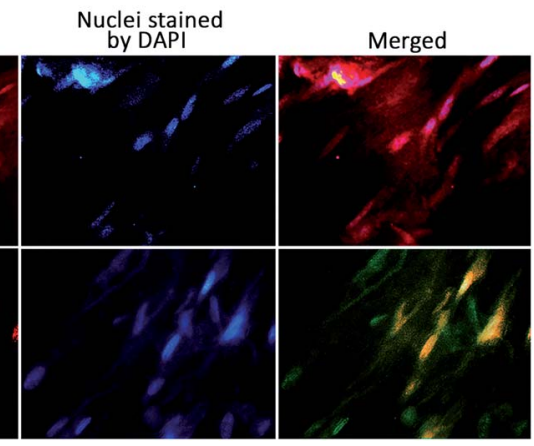

Fig. 5 (a) RT-PCR results for expression of RUNX2 and SOX9 of osteodifferentiated cells $\left(10^{6}\right.$ cells per well) on scaffolds $\left(0.5 \times 0.5 \mathrm{~cm}^{2}\right)$. The expression of $\beta 2 \mathrm{M}$ was recorded as a control gene. (b) ICC results for expression of osteonectin of osteodifferentiated cells on scaffolds after 21 days. The magnification is 400 . 


\section{Conflicts of interest}

There are no conflicts of interest to declare.

\section{Acknowledgements}

Authors gratefully acknowledge the financial support for this study by Iran National Science Foundation (INSF, Project no. 95829362).

\section{References}

1 O. Johnell and J. A. Kanis, Osteoporosis Int., 2006, 17, 17261733.

2 F. Wang, N. Wang, Y. Gao, Z. Zhou, W. Liu, C. Pan, P. Yin, X. Yu and M. Tang, Life Sci., 2017, 174, 15-20.

3 Y. Liu, G. Wu and K. de Groot, J. R. Soc., Interface, 2010, 7, S631-S647.

4 W. Jun, W. Peng, J. Dianming, L. Hong, L. Cong, L. Xing, Q. Xiangyang, C. Yujiang and L. Ming, RSC Adv., 2017, 7, 54306-54312.

5 L. Tao, L. Zhonglong, X. Ming, Y. Zezheng, L. Zhiyuan, Z. Xiaojun and W. Jinwu, RSC Adv., 2017, 7, 54100-54110.

6 A.-M. Yousefi, P. F. James, R. Akbarzadeh, A. Subramanian, C. Flavin and H. Oudadesse, Stem Cells Int., 2016, 2016, 6180487.

7 A. R. Amini, C. T. Laurencin and S. P. Nukavarapu, Critical Reviews in Biomedical Engineering, 2012, 40, 363-408.

8 C.-W. Kao, P.-H. Cheng, P.-T. Wu, S.-W. Wang, I. C. Chen, N.-C. Cheng, K.-C. Yang and J. Yu, RSC Adv., 2017, 7, 51343-51351.

9 Z. Hao, Y. Ma, J. Wu, X. Li, H. Chen, J. Shen and H. Wang, RSC Adv., 2017, 7, 50200-50209.

10 I. Pountos, D. Corscadden, P. Emery and P. V. Giannoudis, Injury, 2007, 38, S23-S33.

11 D. Baksh, L. Song and R. S. Tuan, J. Cell. Mol. Med., 2004, 8, 301-316.

12 N. Zhao, Y. Wang, L. Qin, Z. Guo and D. Li, RSC Adv., 2017, 7, 43186-43196.

13 Z. Mao, Z. Fang, Y. Yang, X. Chen, Y. Wang, J. Kang, X. Qu, W. Yuan and K. Dai, RSC Adv., 2017, 7, 24607-24615.

14 W. L. Grayson, S. Bhumiratana, C. Cannizzaro and G. Vunjak-Novakovic, in Mesenchymal Stem Cell Assays and Applications, Methods in Molecular Biology (Methods and Protocols), ed. M. Vemuri, L. Chase and M. Rao, Humana Press, 2011, vol. 698, pp. 231-241.

15 B. Chuenjitkuntaworn, T. Osathanon, N. Nowwarote, P. Supaphol and P. Pavasant, J. Biomed. Mater. Res., 2016, 104, 264-271.

16 J. Qian, W. Xu, X. Yong, X. Jin and W. Zhang, Mater. Sci. Eng., Proc. Conf., 2014, 36, 95-101.

17 B. C. Isenberg and J. Y. Wong, Mater. Today, 2006, 9, 54-60.

18 A. K. Gaharwar, S. M. Mihaila, A. A. Kulkarni, A. Patel, A. D. Luca, R. L. Reis, M. E. Gomes, C. van Blitterswijk, L. Moroni and A. Khademhosseini, J. Controlled Release, 2014, 187, 66-73.
19 H. Kim, H. W. Kim and H. Suh, Biomaterials, 2003, 24, 46714679.

20 J. B. Lee, J. E. Kim, D. A. Balikov, M. S. Bae, D. N. Heo, D. Lee, H. J. Rim, D.-W. Lee, H.-J. Sung and I. K. Kwon, Macromol. Biosci., 2016, 16, 1027-1103.

21 C. Li, C. Vepari, H.-J. Jin, H. J. Kim and D. L. Kaplan, Biomaterials, 2006, 27, 3115-3124.

22 R. S. Parker, FASEB J., 1996, 10, 542-551.

23 W. Miki, Pure Appl. Chem., 1991, 63, 141-146.

24 A. Masek, E. Chrzescijanska, K. Diakowska and M. Zaborski, Int. J. Electrochem. Sci., 2015, 10, 3372-3386.

25 G. Leatherman, E. N. Durantini, D. Gust, T. A. Moore, A. L. Moore, S. Stone, Z. Zhou, P. Rez, Y. Z. Liu and S. M. Lindsay, J. Phys. Chem. B, 1999, 20, 4006-4010.

26 A.-M. Wu, C.-Q. Huang, Z.-K. Lin, N.-F. Tian, W.-F. Ni, X.-Y. Wang, H.-Z. Xu and Y.-L. Ch, J. Bone Miner. Res., 2014, 29, 2032-2039.

27 M. Sugiura, M. Nakamura, K. Ogawa, Y. Ikoma and M. Yano, PLoS One, 2012, 7, e52643.

28 Y. Nishide, Y. Tousen, M. Tadaishi, M. Inada, C. Miyaura, M. C. Kruger and Y. Ishimi, Int. J. Environ. Res. Public Health, 2015, 12, 13750-13761.

29 M. Tadaishi, Y. Nishide, Y. Tousen, M. C. Kruger and Y. Ishimi, J. Clin. Biochem. Nutr., 2014, 54, 109-115.

30 C. K. Park, Y. Ishimi, M. Ohmura, M. Yamaguchi and S. Ikegami, J. Nutr. Sci. Vitaminol., 1997, 43, 281-296.

31 D. Semnani, M. Nasari and A. Fakhrali, Polym. Bull., 2018, DOI: $10.1007 / \mathrm{s} 00289-017-2141-9$.

32 R. P. Reksamunandar, D. Edikresnha, M. M. Munir, S. Damayanti and Khairurrijala, Procedia Eng., 2017, 170, 19-23.

33 I. Peinado, M. Mason, A. Romano, F. Biasioli and M. Scampicchio, Appl. Surf. Sci., 2016, 370, 111-116.

34 A. Huang, Y. Jiang, B. Napiwocki, H. Mi, X. Peng and L.-S. Turng, RSC Adv., 2017, 7, 43432-43444.

35 C. Zhou, X. Zhou and X. Su, RSC Adv., 2017, 7, 39718-39725.

36 L. D. Shea, D. Wang, R. T. Franceschi and D. J. Mooney, Tissue Eng., Part A, 2000, 6, 605-617.

37 W. J. Li, C. T. Laurencin, E. J. Caterson, R. S. Tuan and F. K. Ko, J. Biomed. Mater. Res., 2002, 60, 613-621.

38 D. Mattinzoli, P. Messa, A. Corbelli, M. Ikehata, C. Zennaro, S. Armelloni, M. Li, L. Giardino and M. P. Rastaldi, Eur. Cells Mater., 2012, 24, 403-425.

39 A. C. Green, T. J. Martin and L. E. Purton, J. Steroid Biochem. Mol. Biol., 2016, 155, 135-146.

40 M. Yamaguchi, J. Biomed. Sci., 2012, 19, 36.

41 S. A. Ross, P. J. McCaffery, U. C. Drager and L. M. De Luca, Physiol. Rev., 2000, 80, 1021-1054.

42 N. Fratzl-Zelman and F. Varga, in Principles of Bone and Joint Research, ed. P. Pietschmann, Springer, Switzerland, 2017, pp. 17-31.

43 G. Jundt, K.-H. Berghäuser, J. D. Termine and A. Schulz, Cell Tissue Res., 1987, 248, 409-415. 